Published in final edited form as:

Bioorg Med Chem. 2012 December 1; 20(23): 6856-6861. doi:10.1016/j.bmc.2012.09.044.

\title{
Synthesis of $\mathrm{N}$-phenyl- $\mathrm{N}$-(3-(piperidin-1-yl)propyl)benzofuran-2- carboxamides as new selective ligands for sigma receptors
}

\author{
Karla-Sue C. Marriott ${ }^{*}$, Andrew Z. Morrison, Misty Moore, Olarongbe Olubajo, and Leonard \\ E. Stewart \\ Department of Natural Sciences, Savannah State University, College of Sciences and \\ Technology, Savannah, Georgia 31404
}

\begin{abstract}
Novel benzofuran-2-carboxamide ligands, which are selective for sigma receptors, have been synthesized via a microwave-assisted Perkin rearrangement reaction and a modified Finkelstein halogen-exchange used to facilitate $\mathrm{N}$-alkylation. The ligands synthesized are the 3-methyl- $N$ phenyl- $N$-(3-(piperidin-1-yl)propyl)benzofuran-2-carboxamides (KSCM-1, KSCM-5 and KSCM-11). The benzofuran-2-carboxamide structure was $N$-arylated and $N$-alkylated to include both $N$-phenyl and $N$-(3-(piperidin-1-yl)propyl substituents respectively. These new carboxamides exhibit high affinity at the sigma-1 receptor with $\mathrm{K}_{\mathrm{i}}$ values ranging from $7.8-34 \mathrm{nM}$. Ligand KSCM-1 with two methoxy substituents at C-5 and C- 6 of the benzofuran ring, and $\mathrm{K}_{\mathrm{i}}=27.5 \mathrm{nM}$ at sigma-1 was found to be more selective for sigma-1 over sigma- 2 .
\end{abstract}

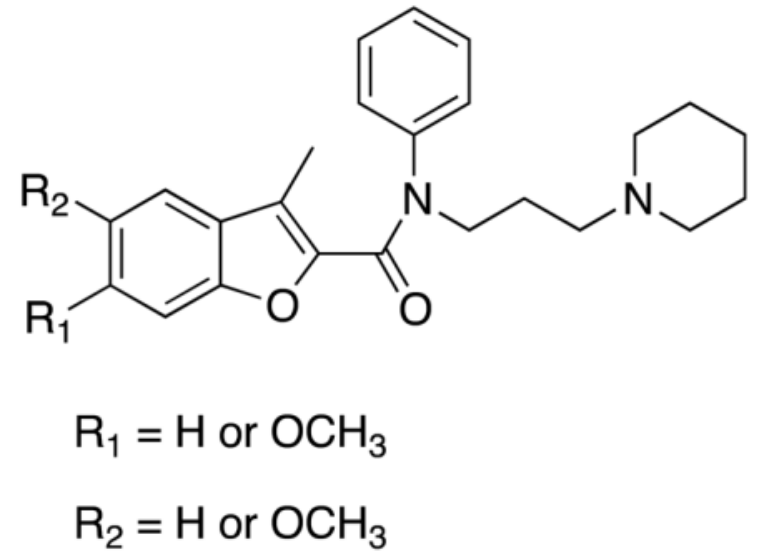

3-methyl- $N$-phenyl- $N$-(3-(piperidin-1-yl)propyl)benzofuran-2-carboxamides

\section{INTRODUCTION}

In the mid-70s sigma receptors were mistakenly characterized as a new subtype of opioid receptors. ${ }^{1}$ However, cloning of the guinea pig sigma-1 binding site in 1996 revealed this

\footnotetext{
(C) 2012 Elsevier Ltd. All rights reserved.

To whom correspondence should be addressed: Karla-Sue C. Marriott, Savannah State University, Department of Natural Sciences, College of Sciences and Technology, 3219 College Street, Savannah, GA 31404, Tel: 912-358-4454. marriottk@ savannahstate.edu.

Publisher's Disclaimer: This is a PDF file of an unedited manuscript that has been accepted for publication. As a service to our customers we are providing this early version of the manuscript. The manuscript will undergo copyediting, typesetting, and review of the resulting proof before it is published in its final citable form. Please note that during the production process errors may be discovered which could affect the content, and all legal disclaimers that apply to the journal pertain.
} 
protein to be unique sharing no homology with any other mammalian protein including all types of molecular chaperones. ${ }^{2}$ Sigma receptors are classified into two subtypes, sigma-1 and sigma-2. To date, the sigma- 2 receptor has not been cloned. Sigma-1 receptors are endoplasmic reticular (ER) proteins consisting of 223-amino acids with a molecular mass of 24-kDa, and two-transmembrane-spanning regions. ${ }^{3,4}$ Sigma-1 receptors are widely distributed throughout the body, centrally and peripherally, primarily functioning in a modulatory role on dopamine, acetylcholine, NMDA and opioid receptors. ${ }^{5}$ They are known to translocate during signal transduction and have been linked to the modulation or production of various intracellular secondary messengers. ${ }^{3,6}$ Sigma-2 receptors are understood to be slightly smaller in size than the sigma-1 receptor. Pharmacological evaluations reveal that sigma-2 receptors may be lipid raft proteins that affect calcium signaling via sphingolipid products and unlike sigma-1 receptors, sigma-2 receptors do not translocate. ${ }^{7}$ Both sigma receptors are highly expressed on tumor cell lines from human and rat cancer tissues. The overexpression of sigma- 2 receptors in human and murine tumors suggests that these receptors may be a biomarker of tumor cell proliferation. ${ }^{7}$

Various drugs, including antipsychotics (morphine analogs), neuroleptics (haloperidol) and neuroactive steroids (progesterone, DHEA), bind to sigma-1 receptors. ${ }^{8}$ Ligands that bind to and modulate the sigma- 1 receptor have been proposed to exhibit effects in several therapeutic areas such as neurodegenerative disorders, pain, depression, schizophrenia, amnesia, Alzheimer's disease, Parkinson's disease and stroke. ${ }^{8}$ Sigma- 1 receptors have also been documented as a target for cocaine and associated with the toxic and stimulant actions of cocaine. ${ }^{7}$ In general sigma- 1 antagonists may have potential use in the treatment of addiction. The binding site of sigma-1 receptors is reported to consist of an amine binding site flanked on either side by hydrophobic binding pockets that display bulk tolerance and as such, typical pharmacophoric features of sigma-1 receptors include an alkylamine moiety within the general molecular structure. ${ }^{9}$ Hence, a common pharmacophoric feature of sigma-1 ligands is an $N$-alkyl, $N, N$-dialkyl or $N$-arylalkyl amine moiety ${ }^{10}$ which poses a challenge in the synthesis of these ligands. Interestingly, progesterone which lacks a basic nitrogen, is considered one of the putative endogenous ligands for the sigma- 1 receptor. ${ }^{11}$ $N, N$-Dimethyltryptamine (DMT) has been identified as a potential endogenous sigma-1 receptor ligand, but, the role of DMT as a sigma-1 receptor modulator is unclear due to low physiological concentrations in brain tissues. ${ }^{12}$ Our synthesized ligands have a benzofuran-2-carboxamide structural moiety which has been $N$-arylated and $N$-alkylated to include both $N$-phenyl and $N$-(3-(piperidin-1-yl)propyl substituents respectively, as summarized structurally in Figure 1. These new carboxamide ligands structurally consist of a basic alkylamine moiety the $N$-(3-(piperidin-1-yl)propyl with a protonatable nitrogen and an aromatic phenyl ring and benzofuran moiety as two hydrophobic residues (Figure 1). Additionally, we introduced structural variations at the benzofuran moiety in the form of methyl ether substituents $\left(\mathrm{R}_{1}\right.$ and $\mathrm{R}_{2}$, Figure 1$)$ to investigate the effect these substituents have on receptor binding affinity.

\section{RESULTS AND DISCUSSION}

\section{Chemistry}

Our microwave-assisted expedited synthetic pathway is straightforward, involving the preparation of 3-methylbenzofuran-2-carboxylic acids (1a and 1b) in quantitative yields via a Perkin rearrangement reaction of mono- and di- methoxy-3-bromocoumarins as previously described. ${ }^{13}$ Mono- and di-hydroxycoumarins were methylated and subsequently brominated at position-3 via a microwave-assisted regioselective bromination with $\mathrm{N}$ bromosuccinimide (NBS) to yield mono- and di- methoxy-3-bromocoumarins in 85-89\% yields. ${ }^{13}$ 
3-Bromocoumarins traditionally undergo base-catalyzed Perkin rearrangement, which requires 3 hours reflux quantitatively yielding benzofuran-2-carboxylic acids. ${ }^{14}$ However under microwave reaction conditions these reactions were completed in 5 minutes. ${ }^{13}$ Monoand di- methoxy-3-methyl-N-phenylbenzofuran-2-carboxamides ( $2 \mathrm{a}$ and $2 \mathrm{~b}$ ) were produced by reacting aniline with the corresponding 3-methylbenzofuran-2-carboxylic acids (1a and $1 b$ ) in the presence of DCC and DMAP at room temperature, as outlined in Scheme 1. 3Methyl- $N$-phenylbenzofuran-2-carboxamide (2c) was produced by condensing commercially available 3-methylbenzofuran-2-carboxylic acid (1c) with aniline.

Syntheses of mono- and di- methoxy-3-methyl-N-phenyl-N-(3-(piperidin-1yl)propyl)benzofuran-2-carboxamides (KSCM-11 and KSCM-1) were achieved by treating carboxamides (2a and 2b) with $\mathrm{NaH}$ followed by $\mathrm{N}$-alkylation with 1-(3iodopropyl)piperidine outlined in Scheme 1. A modified halogen exchange Finkelstein reaction was employed to convert commercially available 1-(3-chloropropyl)piperidine hydrogen chloride salt in the presence of potassium iodide, tetrabutylammonium bromide (TBAB) and potassium carbonate into the more reactive iodopropylpiperidine in situ, which then reacted with anions obtained from treating carboxamides $(2 \mathrm{a}$ and $2 \mathrm{~b})$ with sodium hydride producing KSCM-11 and KSCM-1. 3-Methyl- $N$-phenyl- $N$-(3-(piperidin-1yl)propyl)benzofuran-2-carboxamide (KSCM-5) was similarly synthesized by $\mathrm{N}$-alkylation of carboxamide (2c) with 1-(3-iodopropyl)piperidine.

\section{Binding Assay}

Compounds were screened by the National Institute of Mental Health-Psychoactive Drug Screening Program (NIMH-PDSP) against a panel of G-protein coupled receptors (GPCRs) and molecular targets due to the fact that many ligands with high affinity at sigma receptors have proven to also exhibit significant binding at one or more other central nervous system (CNS) relevant receptor sites. This evaluation has led to the discovery of three new sigma receptor selective ligands. Primary binding assays were performed at serotonin 5-HTs, adrenergic (Alpha1-A, -B, -D, Alpha2-A, -B,-C, Beta-1, -2, -3), cannabinoid (CB1 and CB2), Dopamine (D1-D5), histamine (H1 and H2), opioid (KOR, MOR and DOR), Muscarinic (M1-M5), $N$-methyl-D-aspartate (NMDA), Sigma-1, Sigma-2, metabotropic glutamate (mGluR5 Rat Brain), and benzodiazepine (BZP Rat Brain) receptor sites, as well as, dopamine transporter (DAT), -aminobutyric acid type A (GABAA), norepinephrine transporter (NET) and serotonin transporter (SERT) molecular targets. Compounds showing $>50 \%$ inhibition of radioligand specific binding at the stated GPCRs and molecular targets (Tables 1 and 2) were forwarded for additional screening (secondary binding assays) to determine $\mathrm{K}_{\mathrm{i}}$ values at the respective GPCR binding sites using radioligand binding assays. It was determined that compounds KSCM-1, KSCM-5 and KSCM-11 have the desired selectivity for sigma receptors (sigma-1 and sigma-2) over non-sigma receptors.

Secondary binding assays of these compounds showed greater affinity at sigma receptors over non-sigma receptors such as 5-HT2A, 5-HT2B, 5HT3, Alpha2A, Alpha2C, D3, and M4 (Tables 3 and 4). Consistent with documented sigma-1 receptor ligands, the molecular structures of KSCM-1, KSCM-5 and KSCM-11 include a basic alkyl amine group, flanked by two hydrophobic residues (an aromatic phenyl and benzofuran ring).

Based upon the sigma-1 receptor selective ligand pharmacophore profile [10], a sigma-1 selective ligand usually possesses a primary and secondary hydrophobic site separated by an amine. The sigma- 1 receptor site displays some bulk tolerance and so this prompted us to explore introducing a benzofuran moiety to produce the general molecular structure summarized in Figure 1. All three compounds have an $N$-arylated benzofuran-2carboxamide scaffold which was then $N$-alkylated yielding $N$-(3-(piperidin-1-yl)propyl introducing a basic protonatable nitrogen as well as a three-carbon alkyl linker as 
summarized structurally in Figure 1. Additionally, the benzofuran molecular structure was varied by substitutions at $\mathrm{C}-5$ and $\mathrm{C}-6$ with methyl ether $\left(\mathrm{R}_{1}\right.$ and $\mathrm{R}_{2}$, Figure 1$)$ to explore the impact that introduction of additional hydrogen bond acceptor (HBA) centers would have on receptor binding affinity and selectivity. We observed that the inclusion of methoxy substituents at both C-5 and C- 6 of the benzofuran moiety resulted in both high affinity and selectivity at the sigma-1 receptor over the sigma-2 receptor as observed for KSCM-1 with $\mathrm{K}_{\mathrm{i}}=27.5 \mathrm{nM}$ at sigma- 1 and $528 \mathrm{nM}$ at sigma-2 (19-fold selectivity for sigma- 1 over sigma-2, Table 3). KSCM-1 showed no significant affinity at non-sigma receptors selected for secondary binding assay, $K_{i}$ determination (Table 4), with $K_{i}$ values ranging from 945nM at Alpha2A to 7,612nM at 5-HT3. The exclusion of a methoxy substituent at C-5 of the benzofuran moiety to produce KSCM-11 resulted in a slightly decreased affinity at sigma-1 $\left(\mathrm{K}_{\mathrm{i}}=34 \mathrm{nM}\right.$, Table 3$)$, however, a significant increase in affinity at sigma-2 $\left(\mathrm{K}_{\mathrm{i}}=\right.$ $41 \mathrm{nM}$, Table 3) in comparison to KSCM-1. The mono-methoxy compound KSCM-11 has similar affinity at both sigma receptor binding sites and thus no significant selectivity of sigma-1 over sigma- 2 was observed $\left(K_{i}=34 n M\right.$ at sigma- 1 and $41 \mathrm{nM}$ at sigma-2, Table 3$)$. KSCM-11 showed no significant affinity at non-sigma receptors selected for secondary binding assay, $\mathrm{K}_{\mathrm{i}}$ determination (Table 4 ), with $\mathrm{K}_{\mathrm{i}}$ values ranging from $204 \mathrm{nM}$ at 5 -HT2B to $>10,000 \mathrm{nM}$ at M4. The exclusion of both methoxy substituents at C-5 and C-6 of the benzofuran moiety to produce KSCM-5 resulted in a significantly increased affinity at both sigma-1 $(\mathrm{Ki}=7.8 \mathrm{nM}$, Table 3$)$ and sigma-2 $(\mathrm{Ki}=16 \mathrm{nM}$, Table 3$)$ in comparison to KSCM-1 and KSCM-11. However, selectivity of KSCM-5 for sigma-1 over the sigma-2 was only 2-fold. KSCM-5 showed no significant affinity at non-sigma receptors selected for secondary binding assay, $K_{i}$ determination (Table 4 ), with $K_{i}$ values ranging from $249 n M$ at Alpha2C to $6,739 \mathrm{nM}$ at D3. The sigma-2 receptor secondary binding curves for compounds KSCM-1, KSCM-5, KSCM-11, PDSP control, and haloperidol are shown in Figure 2. The sigma-2 receptor binding curves illustrate the readily noticeable link between affinity at the sigma-2 receptor and the loss of methoxy substituents at C- 5 and C- 6 of the benzofuran ring. Compound KSCM-5 without methoxy substituents was found to be a potent sigma-2 ligand with comparable potency to haloperidol at sigma- 2 as is readily discernible from the binding curve (Figure 2).

\section{CONCLUSION}

In this study, we have identified three new sigma receptor selective ligands based on features of the sigma-1 receptor binding site which consists of an amine binding site flanked on either side by hydrophobic binding pockets. All three ligands have high affinity at sigma-1 with $\mathrm{K}_{\mathrm{i}}$ values ranging from $7.8-34 \mathrm{nM}$. KSCM-1 was the most selective with $\mathrm{K}_{\mathrm{i}}=$ $27.5 \mathrm{nM}$ at sigma- 1 and a 19 -fold selectivity for sigma- 1 over sigma-2. Ligands KSCM-1, KSCM-5 and KSCM-11 all possess basic nitrogen atoms and are structurally composed of benzofuran-2-carboxamide moieties which have been $N$-arylated and $N$-alkylated to include both $N$-phenyl and $N$-(3-(piperidin-1-yl)propyl substituents. The expedited synthetic procedures employed include regioselective microwave-assisted NBS bromination as well as microwave-assisted Perkin rearrangement reactions to prepare benzofuran-2-carboxylic acids (1a and $1 \mathrm{~b}$ ) from the corresponding 3-bromocoumarins in very high yields.

\section{EXPERIMENTAL SECTION}

${ }^{1} \mathrm{H}$ and ${ }^{13} \mathrm{C}$ NMR spectra were recorded on a JEOL $300 \mathrm{MHz}$ spectrometer. Chemical shifts for ${ }^{1} \mathrm{H}$ and ${ }^{13} \mathrm{C}$ NMR spectra are reported in values (parts per million, ppm) relative to an internal standard of tetramethylsilane (TMS) in $\mathrm{CDCl}_{3}$. Multiplicities are presented as follows: $\mathrm{s}=$ singlet, $\mathrm{d}=$ doublet, $\mathrm{t}=$ triplet, $\mathrm{q}=$ quartet, $\mathrm{qt}=$ quintuplet, $\mathrm{m}=$ multiplet. Microwave syntheses were carried out on a CEM MarsXpress. HRMS data were obtained in the Mass Spectrometry Laboratory, School of Chemical Sciences, University of Illinois. 
Solvents were purified using standard procedures. TLC analyses were performed on Fluka $200 \mu \mathrm{m}$ Silica Gel particle size $25 \mu \mathrm{m} \mathrm{F}_{254}$ plates and visualized by quenching of UV fluorescence $\left(\lambda_{\max }=254 \mathrm{~nm}\right)$. All new compounds were purified on a Biotage Isolera-4 flash purification system using the indicated SNAP cartridges and solvents as eluents.

\section{In Vitro Characterization, Primary and Secondary Binding Experiments}

Radioligand binding assays using cloned G-protein coupled receptors (GPCRs), ion channels, and transporters were performed by the National Institute of Mental HealthPsychoactive Drug Screening Program (NIMH-PDSP) using membranes from transiently transfected or stable cell lines. Detailed protocols (including cell handling, buffer composition, assay conditions, etc.) for all assays are available online (http:// pdsp.med.unc.edu/). Initial primary binding screening assays were performed using a $50 \mu \mathrm{M}$ (initial) $-10 \mu \mathrm{M}$ (final) assay concentration of reference and test compounds. The percent inhibition of specific binding by the test compound was determined and if the test compound inhibited $>50 \%$ of radioligand specific binding, then secondary binding assays $\mathrm{K}_{\mathrm{i}}$ determinations were performed. Secondary binding assays, $\mathrm{K}_{\mathrm{i}}$ determinations were performed by measuring the inhibition of radioligand binding by various concentrations of test and reference compound. In summary, compounds/ligands were prepared as a $1.0 \mathrm{mg} / \mathrm{ml}$ stock in Standard Binding Buffer (50 mM Tris HCl pH 8.0) or DMSO according to the solubility of the compound. A similar stock of Haloperidol was also prepared as a reference for a positive control. Dilutions of the test and reference compounds were then prepared in Standard Binding Buffer: $0.05 \mathrm{nM}, 0.5 \mathrm{nM}, 1.5 \mathrm{nM}, 5 \mathrm{nM}, 50 \mathrm{nM}, 150 \mathrm{nM}, 500 \mathrm{nM}, 1.5$ $\mu \mathrm{M}, 5 \mu \mathrm{M}$ and $50 \mu \mathrm{M}$. $\left[{ }^{3} \mathrm{H}\right]$ Pentazocine $(3 \mathrm{nM})$ was used as the radioligand for sigma-1 receptors and $\left[{ }^{3} \mathrm{H}\right]$ Ditolyglguanidine (DTG) $(1 \mathrm{nM})$ as the radioligand for sigma-2 receptors. Aliquots $(50 \mu \mathrm{l})$ of radioligand were dispensed into the wells of a 96- well plate containing $100 \mu l$ of Standard Binding Buffer. Then, duplicate 50- $\mu 1$ aliquots of the test and reference compound dilutions were added. Finally, either crude membrane fractions prepared from rat brain homogenate for sigma- 1 receptors or PC12 cell homogenates for sigma- 2 receptors were added to the wells, and the plates shielded from light to prevent photolysis of light sensitive ligands. For sigma-1 receptors, the reactions were incubated at $37^{\circ} \mathrm{C}$ for $2.5 \mathrm{hrs}$, and for sigma-2 receptors, the reactions were incubated at room temperature for $2 \mathrm{hrs}$. Labeled receptors were harvested by rapid filtration on to Whatman GF/B glass filters presoaked with $0.3 \%$ polyethyleneimine using 96 -well Brandel harvester. Four rapid $500 \mu 1$ washes are performed with chilled Standard Binding buffer to reduce non-specific binding. Filters were placed in 6-ml scintillation tubes and allowed to dry overnight. EcoScint scintiallation cocktail (National Diagnostics) was added to each tube prior to counting. For higher throughput assays, bound radioactivity was harvested onto $0.3 \%$ polyethyleneiminetreated, 96-well filter mats using a 96 well Filtermate harvester. The filter mats were dried, the scintillate melted onto the filters and the radioactivity counted in a Microbeta scintillation counter. Raw data (dpm) representing total radioligand binding (i.e., specific + nonspecific binding) were plotted as a function of the logarithm of the molar concentration of the competitor (i.e., test or reference compound). Non-linear regression of the normalized (i.e., percent radioligand binding compared to that observed in the absence of test or reference compound) raw data was performed in Prism 4.0 (GraphPad Software) using builtin three parameter logistic model describing ligand competition binding to radioligandlabeled sites: $\mathrm{y}=$ bottom $+\left[(\right.$ top-bottom $\left.) /\left(1+10 \mathrm{x}-\log \mathrm{IC}_{50}\right)\right]$ where bottom equals the residual radioligand binding measured in the presence of $10 \mathrm{mM}$ reference (i.e., non-specific binding) and top equals the total radioligand binding observed in the absence of competitor. The $\log \mathrm{IC}_{50}$ (i.e., the $\log$ of the ligand concentration that reduces radioligand binding by $50 \%$ ) was thus estimated from the data and used to obtain the $\mathrm{K}_{\mathrm{i}}$ by applying the ChengPrusoff approximation. 


\section{Ligand Synthesis}

6-Methoxy-3-methyl- $\mathrm{N}$-phenylbenzofuran-2-carboxamide (2a)-To a mixture of aniline $(0.689 \mathrm{~g}, 7.4 \mathrm{mmol})$ in dichloromethane $(25 \mathrm{~mL})$, 3-methyl-6-methoxybenzofuran-2carboxylic acid (1a) $(1.501 \mathrm{~g}, 7.3 \mathrm{mmol})$ was added with stirring. Then DMAP $(0.094 \mathrm{~g}$, $0.77 \mathrm{mmol})$ was added, followed by DCC $(1.583 \mathrm{~g}, 7.7 \mathrm{mmol})$. The reaction was left to stir at room temperature for $23 \mathrm{~h}$. The reaction mixture was then filtered and the filtrate washed with water $(20 \mathrm{~mL} \times 2)$, then $5 \%$ acetic acid $(20 \mathrm{~mL} \times 2)$ and again with water $(20 \mathrm{~mL} \times 2)$. The crude product was recrystallized from methanol to yield $\mathbf{2 a}$ as white crystals $(1.37 \mathrm{~g}$, 67\%), mp 176-178 ${ }^{\circ} \mathrm{C} .{ }^{1} \mathrm{H}$ NMR (300 MHz, $\left.\mathrm{CDCl}_{3}\right) \delta 2.64(\mathrm{~s}, 3 \mathrm{H}), 3.88(\mathrm{~s}, 3 \mathrm{H}), 6.93-7.00$ (m, 2H), 7.12- 7.16 (t, J = 7.41 Hz, 1H) 7.35-7.40 (t, J = 7.65 Hz, 2H), 7.48-7.50 (d, J = 8.6 $\mathrm{Hz}, 1 \mathrm{H}), 7.68-7.71(\mathrm{~d}, \mathrm{~J}=8.5 \mathrm{~Hz}, 2 \mathrm{H}), 8.26(\mathrm{~s}, 1 \mathrm{H}) .{ }^{13} \mathrm{C} \mathrm{NMR}\left(300 \mathrm{MHz}, \mathrm{CDCl}_{3}\right) \delta 9.2$, 55.8, 95.6, 112.9, 119.9, 121.4, 123.3, 124.4, 129.1, 137.7, 141.8, 154.5, 158.1, 160.5 . MS(ESI) ${ }^{+}$calcd for $\mathrm{C}_{17} \mathrm{H}_{16} \mathrm{NO}_{3}[\mathrm{M}+\mathrm{H}]^{+}: 282.1130$, found: 282.1124 .

5,6-Dimethoxy-3-methyl- $\mathrm{N}$-phenylbenzofuran-2-carboxamide (2b)-To a mixture of aniline $(0.398 \mathrm{~g}, 4.27 \mathrm{mmol})$ in dichloromethane $(15 \mathrm{~mL})$, 3-methyl-5,6dimethoxybenzofuran-2-carboxylic acid (1b) $(1.005 \mathrm{~g}, 4.25 \mathrm{mmol})$ was added with stirring. Then DMAP $(0.090 \mathrm{~g}, 0.44 \mathrm{mmol})$ was added, followed by DCC $(0.934 \mathrm{~g}, 4.53 \mathrm{mmol})$. The reaction was left to stir at room temperature for $23 \mathrm{~h}$. The reaction mixture was then filtered and the filtrate washed with water $(20 \mathrm{~mL} \times 2)$, then $5 \%$ acetic acid $(20 \mathrm{~mL} \times 2)$ and again with water $(20 \mathrm{~mL} \times 2)$. The crude product was recrystallized from methanol to yield $\mathbf{2 b}$ as white crystals $(0.94 \mathrm{~g}, 71 \%), \mathrm{mp} 183-185^{\circ} \mathrm{C} .{ }^{1} \mathrm{H}$ NMR $\left(300 \mathrm{MHz}, \mathrm{CDCl}_{3}\right) \delta 2.64(\mathrm{~s}, 3 \mathrm{H})$, $3.95(\mathrm{~s}, 6 \mathrm{H}), 6.97(\mathrm{~s}, 1 \mathrm{H}), 6.99(\mathrm{~s}, 1 \mathrm{H}) 7.12-7.72(\mathrm{~m}, 5 \mathrm{H}), 8.26(\mathrm{~s}, 1 \mathrm{H}) .{ }^{13} \mathrm{C}$ NMR $(300$ $\left.\mathrm{MHz}, \mathrm{CDCl}_{3}\right) \delta$ 9.2, 56.3, 56.4, 94.9, 101.2, 119.8, 121.7, 124.3, 129.1, 137.7, 141.8, 147.2, 148.3, 150.8, 158.0. MS(ESI) ${ }^{+}$calcd for $\mathrm{C}_{18} \mathrm{H}_{18} \mathrm{NO}_{4}[\mathrm{M}+\mathrm{H}]^{+}: 312.1236$, found: 312.1235 .

3-Methyl-N-phenylbenzofuran-2-carboxamide (2c)-To a mixture of aniline $(0.690 \mathrm{~g}, 7.41 \mathrm{mmol})$ in dichloromethane $(25 \mathrm{~mL}), 3$-methylbenzofuran-2-carboxylic acid (1c) $(1.00 \mathrm{~g}, 5.7 \mathrm{mmol})$ was added with stirring. Then DMAP $(0.116 \mathrm{~g}, 0.57 \mathrm{mmol})$ was added, followed by DCC $(1.220 \mathrm{~g}, 5.9 \mathrm{mmol})$. The reaction was left to stir at room temperature for $23 \mathrm{~h}$. The reaction mixture was then filtered and the filtrate washed with water $(20 \mathrm{~mL} \times 2)$, then $5 \%$ acetic acid $(20 \mathrm{~mL} \times 2)$ and again with water $(20 \mathrm{~mL} \times 2)$. The crude product was recrystallized from methanol to yield $\mathbf{2 c}$ as off-white crystals $(0.896 \mathrm{~g}, 63 \%), \mathrm{mp} 118-120$ ${ }^{\circ} \mathrm{C} .{ }^{1} \mathrm{H}$ NMR $\left(300 \mathrm{MHz}, \mathrm{CDCl}_{3}\right) \delta 2.68(\mathrm{~s}, 3 \mathrm{H}), 7.13-7.18(\mathrm{t}, J=7.4 \mathrm{~Hz}, 1 \mathrm{H}), 7.30-7.52$ $(\mathrm{m}, 5 \mathrm{H}), 7.62-7.65(\mathrm{~d}, J=7.57 \mathrm{~Hz}, 1 \mathrm{H}) 7.72-7.73(\mathrm{~d}, J=8.57 \mathrm{~Hz}, 2 \mathrm{H}), 8.35(\mathrm{~s}, 1 \mathrm{H}) .{ }^{13} \mathrm{C}$ NMR $\left(300 \mathrm{MHz}, \mathrm{CDCl}_{3}\right) \delta 9.1,111.6,120.0,121.1,123.4,123.9,124.6,127.5,129.2$, 129.9, 137.5, 142.4, 153.3, 158.1. MS(ESI) ${ }^{+}$calcd for $\mathrm{C}_{16} \mathrm{H}_{14} \mathrm{NO}_{2}[\mathrm{M}+\mathrm{H}]^{+}: 252.1025$, found: 252.1027 .

\section{5,6-Dimethoxy-3-methyl-N-phenyl-N-(3-(piperidin-1-yl)propyl)benzofuran-2- carboxamide (KSCM-1)—Compound $\mathbf{2 b}(0.100 \mathrm{~g}, 0.321 \mathrm{mmol})$ was added to dry} dichloromethane $(15 \mathrm{~mL})$ with stirring under nitrogen atmosphere. To this solution $\mathrm{NaH}$ $(0.130 \mathrm{~g}, 3.25 \mathrm{mmol}) 60 \%$ dispersion in mineral oil was added and the reaction heated at reflux for $1 \mathrm{~h}$. The reaction mixture was then cooled in an ice-bath and 1-(3chloropropyl)piperidine hydrogen chloride salt $(0.110 \mathrm{~g}, 0.555 \mathrm{mmol})$, potassium carbonate $(0.380 \mathrm{~g}, 2.75 \mathrm{mmol})$, tetrabutylammoniumbromide $(0.046 \mathrm{~g}, 0.143 \mathrm{mmol})$ and potassium iodide $(0.292 \mathrm{~g}, 1.76 \mathrm{mmol})$ added with stirring. The reaction mixture was then heated at reflux for $24 \mathrm{~h}$. The reaction mixture was then cooled and slowly quenched with ethanol. The reaction mixture was washed with water $(5 \mathrm{ml} \times 2)$ and the organic layer dried over magnesium sulfate. The crude product was purified by high performance flash purification using a Biotage Isolera 4 system, $\mathrm{SNAP}\left(\mathrm{SiO}_{2}\right) \mathrm{KP}-\mathrm{NH}$ column, solvent dichloromethane/ methanol (9:1) as eluent to give $0.0841 \mathrm{~g}(60 \%)$ of KSCM-1 as a light brown paste. ${ }^{1} \mathrm{H}$ NMR 
(300 MHz, $\left.\mathrm{CDCl}_{3}\right) 1.38-1.56(\mathrm{~m}, 6 \mathrm{H}), 1.81-1.91$ (qt, J = 7.58 Hz, 2H), 2.31-2.36 (m, 6H), $2.34(\mathrm{~s}, 3 \mathrm{H}), 3.80(\mathrm{~s}, 3 \mathrm{H}), 3.87(\mathrm{~s}, 3 \mathrm{H}), 3.86-3.93(\mathrm{~m}, 2 \mathrm{H}), 6.52(\mathrm{~s}, 1 \mathrm{H}), 6.81(\mathrm{~s}, 1 \mathrm{H}), 7.10-$ $7.30(\mathrm{~m}, 5 \mathrm{H}) .{ }^{13} \mathrm{C} \mathrm{NMR}\left(300 \mathrm{MHz}, \mathrm{CDCl}_{3}\right)$ 9.9, 10.1, 24.5, 25.3, 26.0, 29.7, 49.0, 54.6, 56.2, 56.3, 56.6 94.7, 100.8, 120.8, 122.4, 126.5, 126.9, 128.9, 143.2, 143.6, 146.7, 148.4, 149.9, 161.4. MS(ESI) ${ }^{+}$calcd for $\mathrm{C}_{26} \mathrm{H}_{33} \mathrm{~N}_{2} \mathrm{O}_{4}[\mathrm{M}+\mathrm{H}]^{+}:$437.2440, found: 437.2440.

\section{3-Methyl-N-phenyl-N-(3-(piperidin-1-yl)propyl)benzofuran-2-carboxamide} (KSCM-5)-Compound 2c $(0.200 \mathrm{~g}, 0.80 \mathrm{mmol})$ was added to dry dichloromethane $(25 \mathrm{ml})$ with stirring under nitrogen atmosphere. To this solution $\mathrm{NaH}(290 \mathrm{mg}, 7.25 \mathrm{mmol}) 60 \%$ dispersion in mineral oil was added and at reflux for $1 \mathrm{~h}$. The reaction mixture was cooled in an ice-bath and 1-(3-chloropropyl)piperidine hydrogen chloride salt $(0.238 \mathrm{~g}, 1.2 \mathrm{mmol})$, potassium carbonate $(0.660 \mathrm{~g}, 4.8 \mathrm{mmol})$, tetrabutylammoniumbromide $(0.100 \mathrm{~g}, 0.310 \mathrm{mmol})$ and potassium iodide $(0.299 \mathrm{~g}, 1.8 \mathrm{mmol})$ added with stirring. The reaction mixture was reflux for $24 \mathrm{~h}$. The reaction mixture was then cooled and slowly quenched with ethanol. The reaction mixture was washed with water $(10 \mathrm{ml} \times 2)$ and the organic layer dried over magnesium sulfate. The crude product was purified by high performance flash purification using a Biotage Isolera 4 system, $\mathrm{SNAP}\left(\mathrm{SiO}_{2}\right) \mathrm{KP}-\mathrm{NH}$ column, solvent dichloromethane/ methanol (9:1) as eluent to give $0.189 \mathrm{~g}(63 \%)$ of KSCM-5 as a light brown paste. ${ }^{1} \mathrm{H}$ NMR $\left(300 \mathrm{MHz} \mathrm{CDCl}_{3}\right) 1.36-1.56(\mathrm{~m}, 6 \mathrm{H}), 1.82-1.92(\mathrm{qt}, \mathrm{J}=7.58 \mathrm{~Hz}, 2 \mathrm{H}), 2.31-2.36(\mathrm{~m}, 6 \mathrm{H})$, 2.34 (s, 3H), 3.90-3.95 (t, J = 7.64 Hz, 2H), 7.03-7.05 (d, J = 8.03 Hz, 1H), 7.11- 7.26 (m, 7H), 7.43-7.45 (d, J = 6.85 Hz, 1H). ${ }^{13} \mathrm{C}$ NMR (300 MHz, $\mathrm{CDCl}_{3}$ ) 9.1, 24.5, 25.3, 26.0, 49.0, 54.6, 56.6, 111.4, 120.3, 121.2, 122.6, 126.2, 126.7, 127.0, 128.9, 129.0, 142.8, 144.4, 153.4, 161.5. MS(ESI) ${ }^{+}$calculated for $\mathrm{C}_{24} \mathrm{H}_{29} \mathrm{~N}_{2} \mathrm{O}_{2}[\mathrm{M}+\mathrm{H}]^{+}: 377.2229$, found: 377.2227 .

\section{6-Methoxy-3-methyl-N-phenyl-N-(3-(piperidin-1-yl)propyl)benzofuran-2- carboxamide (KSCM-11)—Compound 2a $(0.200 \mathrm{~g}, 0.71 \mathrm{mmol})$ was added to dry} dichloromethane $(25 \mathrm{~mL})$ with stirring under nitrogen atmosphere. To this solution $\mathrm{NaH}$ $(0.290 \mathrm{~g}, 7.25 \mathrm{mmol}) 60 \%$ dispersion in mineral oil was added and the reaction heated at reflux for $1 \mathrm{~h}$. The reaction mixture was then cooled in an ice-bath and 1-(3-

chloropropyl)piperidine hydrogen chloride salt $(0.238 \mathrm{~g}, 1.2 \mathrm{mmol})$, potassium carbonate $(0.660 \mathrm{~g}, 4.8 \mathrm{mmol})$, tetrabutylammoniumbromide $(0.090 \mathrm{~g}, 0.279 \mathrm{mmol})$ and potassium iodide $(0.357 \mathrm{~g}, 2.15 \mathrm{mmol})$ added with stirring. The reaction mixture was then heated at reflux for $24 \mathrm{~h}$. The reaction mixture was then cooled and slowly quenched with ethanol. The reaction mixture was washed with water $(10 \mathrm{ml} \times 2)$ and the organic layer dried over magnesium sulfate. The crude product was purified by high performance flash purification using a Biotage Isolera 4 system, $\mathrm{SNAP}\left(\mathrm{SiO}_{2}\right) \mathrm{KP}-\mathrm{NH}$ column, solvent dichloromethane/ methanol (9:1) as eluent to give $0.168 \mathrm{~g}(58 \%)$ of KSCM-11 as a brown paste. ${ }^{1} \mathrm{H}$ NMR (300 $\mathrm{MHz} \mathrm{CDCl}_{3}$ ) 1.39-1.57 (m, 6H), 1.82-1.92 (qt, J = 7.14 Hz, 2H), 2.33-2.37 (m, 6H), 2.35 (s, 3H), $3.74(\mathrm{~s}, 3 \mathrm{H}), 3.90-3.95(\mathrm{t}, \mathrm{J}=7.57 \mathrm{~Hz}, 2 \mathrm{H}), 6.52(\mathrm{~s}, 1 \mathrm{H}), 6.78-6.80$ (d, J = 8.61 Hz, 1H), 7.12- $7.33(\mathrm{~m}, 6 \mathrm{H}) .{ }^{13} \mathrm{C} \mathrm{NMR}\left(300 \mathrm{MHz} \mathrm{CDCl}_{3}\right)$ 9.2, 24.5, 25.3, 26.0, 49.0, 54.6, 55.6, 56.6, 95.3, 112.3, 120.6, 122.1, 122.4, 126.6, 127.0, 129.0, 143.1, 143.6, 154.6, 159.6, 161.4. MS(ESI) ${ }^{+}$calcd for $\mathrm{C}_{25} \mathrm{H}_{31} \mathrm{~N}_{2} \mathrm{O}_{3}[\mathrm{M}+\mathrm{H}]^{+}: 407.2335$, found: 407.2339 .

\section{Supplementary Material}

Refer to Web version on PubMed Central for supplementary material.

\section{Acknowledgments}

Special thanks and appreciation are extended to the NIMH Psychoactive Drug Screening Program (PDSP).

[Ki determinations, receptor binding profiles, agonist and/or antagonist functional data, HERG data, MDR1 data, etc. as appropriate] was generously provided by the National Institute of Mental Health's Psychoactive Drug Screening Program, Contract \# HHSN-271-2008-00025-C (NIMH PDSP). The NIMH PDSP is Directed by Bryan 
L. Roth MD, PhD at the University of North Carolina at Chapel Hill and Project Officer Jamie Driscol at NIMH, Bethesda MD, USA. For experimental details please refer to the PDSP web site http://pdsp.med.unc.edu/ and click on "Binding Assay" or "Functional Assay" on the menu bar (experimental details have been updated!).

Thanks also extended to John C. Watts (external advisor), Savannah, GA.

Karla-Sue C. Marriott received support for this work from the National Institute of Health/National Institute on Drug Abuse (NIH/NIDA) (DA027086).

\section{References}

1. Martin WR, Eades CG, Thompson JA, Huppler RE, Gilbert PE. J Pharmacol Exp Ther. 1976; 197:517. [PubMed: 945347]

2. Hanner M, Moebius FF, Flandorfer A, Knaus HG, Striessnig J, Kempner E, Glossmann H. Proc Natl Acad Sci U S A. 1996; 93:8072. [PubMed: 8755605]

3. Aydar E, Palmer CP, Klyachko VA, Jackson MB. The receptor as a ligand-regulated auxillary potassium channel subunit. Neuron. 2002; 34:399-410. [PubMed: 11988171]

4. Jbilo O, Vidal H, Paul R, et al. Purification and characterization of the human SR31747A-binding protein. A nuclear membrane protein related to yeast sterol isomerase. J Biol Chem. 1997; 272:27107-27115. [PubMed: 9341151]

5. Bowen WD. receptors: recent advances and new clinical potentials. Pharma Acta Helv. 2000; 74:211-218.

6. Hayashi T, Su TP. Regulating ankyrin dynamics: roles of -1 receptors. Proc Natl Acad Sci U S A. 2001; 98:491-496. [PubMed: 11149946]

7. Narayanan S, Mesangeau C, Poupaert J, McCurdy C. Sigma receptors and cocaine abuse. Curr Topics in Med Chem. 2011; 9:1128-50.

8. Valade A, Cross SB, Brown C, Detrait E, Ene D, Gillard M, Guyaux M, Lamberty Y, Maguire M, Namdev N, Provins L, Schwartz E, Vermeiren C. Discovery of novel selective Sigma-1 ligands as cognitive enhancers. Med Chem Commun. 2011; 2:655.

9. Glennon RA. Mini-Rev Med Chem. 2005; 5:927. [PubMed: 16250835]

10. Ablordeppey SY, Fischer JB, Glennon RA. Is a nitrogen atom an important pharmacophoric element in sigma ligand binding? Bioorg Med Chem. 2000; 8(8):2105-2111. [PubMed: 11003156]

11. Hayashi T, Su TP. Sigma-1 receptor ligands: potential in the treatment of neuropsychiatric disorders. CNS Drugs. 2004; 18:269-284. [PubMed: 15089113]

12. Fontanilla D, Johannessen M, Hajipour AR, Cozzi NV, Jackson MB, Ruoho AE. The hallucinogen $\mathrm{N}, \mathrm{N}$-dimethyltryptamine (DMT) is an endogenous sigma-1 receptor regulator. Science. 2009; 323:934-937. [PubMed: 19213917]

13. Marriott K-SC, Bartee R, Morrison AZ, Stewart L, Wesby J. Expedited synthesis of benzofuran-2carboxylic acids via microwave-assisted Perkin rearrangement reaction. Tetrahedron Letters 2012. 2012; 53(26):3319-3321.10.1016/j.tetlet.2012.04.075

14. Jackson YA, Marriott KSC. Synthesis of 2,3-Dimethoxy-7-methyl-7,12-dihydro-6H-[1]benzofuro-[2,3-c]-[1]-benzazepin-6,12-dione. Molecules. 2002; 7:353-362. 
<smiles>[R]c1cc2oc(C(=O)N([R5])c3ccccc3)c(C)c2cc1[R]</smiles>

$$
\begin{aligned}
& \mathrm{R}_{1}=\mathrm{H} \text { or } \mathrm{OCH}_{3} \\
& \mathrm{R}_{2}=\mathrm{H} \text { or } \mathrm{OCH}_{3}
\end{aligned}
$$

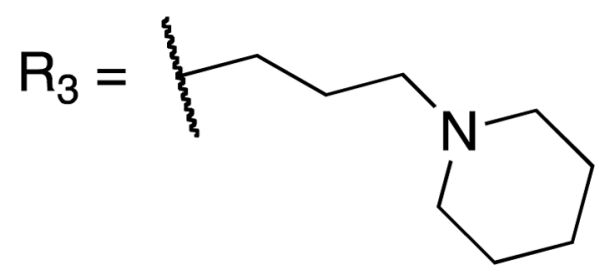

Figure 1.

General ligand structure 

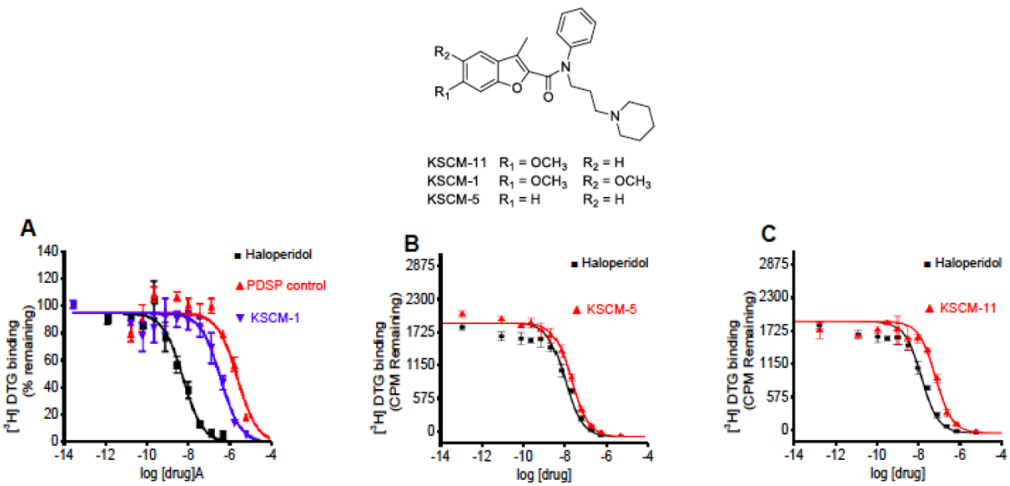

Figure 2.

Secondary binding curves for $\mathrm{K}_{\mathrm{i}}$ determinations of new ligands at sigma-2. Ligand binding of KSCM-1 (A), KSCM-5 (B) and KSCM-11 (C) at sigma-2 receptors. Sigma-2 receptors were labeled with $\left[{ }^{3} \mathrm{H}\right] \mathrm{DTG}$ and haloperidol as the reference ligand. 
<smiles>[R]c1cc2oc(C(=O)O)c(C)c2cc1[R]</smiles>

1a, $\mathrm{R}_{1}=\mathrm{OCH}_{3}, \mathrm{R}_{2}=\mathrm{H}$

2a, $\mathrm{R}_{1}=\mathrm{OCH}_{3}, \mathrm{R}_{2}=\mathrm{H}$

1b, $\mathrm{R}_{1}=\mathrm{OCH}_{3}, \mathrm{R}_{2}=\mathrm{OCH}_{3}$

2b, $\mathrm{R}_{1}=\mathrm{OCH}_{3}, \mathrm{R}_{2}=\mathrm{OCH}_{3}$

1c, $\mathrm{R}_{1}=\mathrm{H}, \mathrm{R}_{2}=\mathrm{H}$

2c, $\mathrm{R}_{1}=\mathrm{H}, \mathrm{R}_{2}=\mathrm{H}$

KSCM-11, $\mathrm{R}_{1}=\mathrm{OCH}_{3}, \mathrm{R}_{2}=\mathrm{H}$

KSCM-1, $\mathrm{R}=\mathrm{OCH}_{3}, \mathrm{R}_{2}=\mathrm{OCH}_{3}$

KSCM-5, $\mathrm{R}_{1}=\mathrm{H}, \mathrm{R}_{2}=\mathrm{H}$

Scheme 1.

Reagents: a) DCC, DMAP, aniline, $\mathrm{CH}_{2} \mathrm{Cl}_{2}$; b) $\mathrm{NaH}$, 1-(3-chloropropyl)piperidine.HCl, $\mathrm{K}_{2} \mathrm{CO}_{3}$, KI, TBAB, $\mathrm{CH}_{2} \mathrm{Cl}_{2}$. 


\section{Table 1}

\section{Primary Binding Assay at Sigma Receptors}

\begin{tabular}{lll}
\hline \multicolumn{3}{c}{ \% Inhibition } \\
\hline Compound & $\mathbf{- 1}$ & $\mathbf{- 2}$ \\
\hline KSCM-1 & 99.8 & 81.4 \\
KSCM-5 & 100.6 & 93.5 \\
KSCM-11 & 97.7 & 88.5 \\
\hline
\end{tabular}

Primary binding assays performed in sigma binding buffer $(50 \mathrm{mM}$ Tris- $\mathrm{HCl}, \mathrm{pH} 8.0)$. Sigma-1 receptors were labeled with $\left[{ }^{3} \mathrm{H}\right](+)-\mathrm{pentazocine}$ and sigma-2 receptors were labeled with $\left[{ }^{3} \mathrm{H}\right]$ Ditolylguanidine (DTG) with haloperidol as the reference compound in both cases. Data represent mean $\%$ inhibition $(\mathrm{N}=4$ determinations) for compound tested at receptor subtypes. Significant inhibition is considered $>50 \%$. In cases where negative inhibition (-) is seen, this represents a stimulation of binding. Occasionally, compounds at high concentrations will non-specifically increase binding. The default concentration for primary binding experiments is $10 \mathrm{uM}$. 


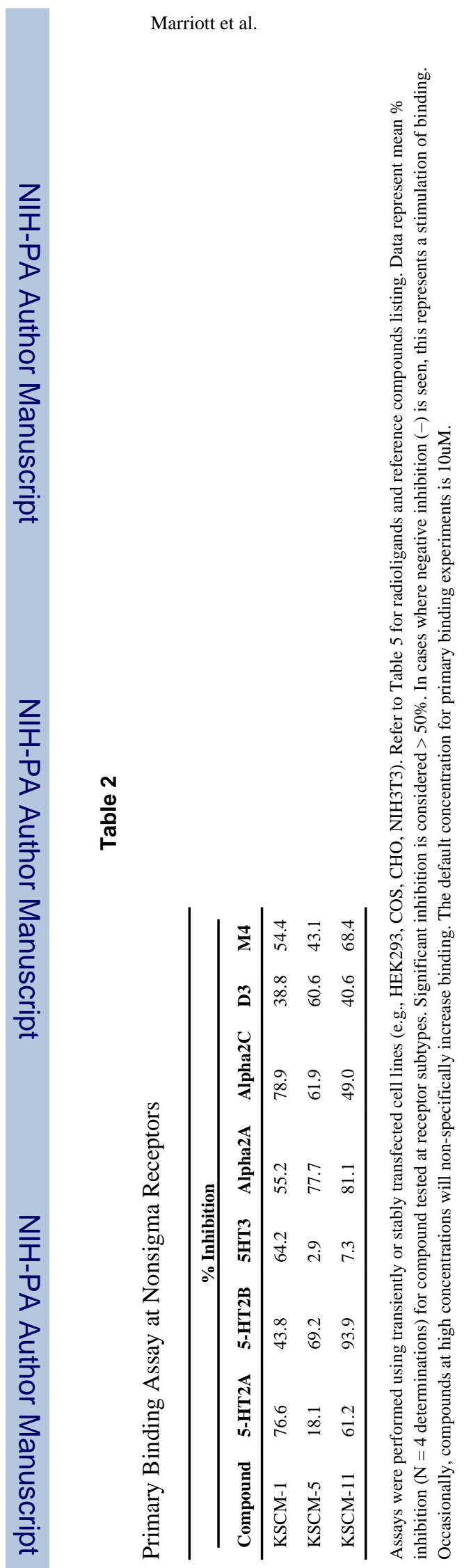

Bioorg Med Chem. Author manuscript; available in PMC 2013 December 01. 


\section{Table 3}

Secondary Binding Assay, $\mathrm{K}_{\mathrm{i}}$ Determination at Sigma Receptors

\begin{tabular}{llll}
\hline Compound & $\mathbf{- 1}\left(\mathbf{K}_{\mathbf{i}}, \mathbf{n M}\right)$ & $\mathbf{- 2}\left(\mathbf{K}_{\mathbf{i}}, \mathbf{n M}\right)$ & $\mathbf{- 2 / - 1}$ \\
\hline KSCM-1 & 27.5 & 528 & 19 \\
KSCM-5 & 7.8 & 16 & 2 \\
KSCM-11 & 34 & 41 & 1.2 \\
Haloperidol & 1.7 & 13 & 8 \\
\hline
\end{tabular}

Affinities $\mathrm{K}_{\mathrm{i}}(\mathrm{nM})$ were determined in rat brain homogenate (sigma-1), PC12 cells (sigma-2), sigma binding buffer (50 mM Tris- $\mathrm{HCl}$, $\mathrm{pH} 8.0$ ). Sigma-1 receptors were labeled with $\left[{ }^{3} \mathrm{H}\right](+)$ - pentazocine and sigma-2 receptors were labeled with $\left[{ }^{3} \mathrm{H}\right] \mathrm{DTG}$ with haloperidol as the reference compound in both cases. 
Table 5

Assay Conditions for Radioligand Binding Assays

\begin{tabular}{lll}
\hline Receptor & Radioligand & Reference compound \\
\hline Sigma-1 & {$\left[{ }^{3} \mathrm{H}\right]$ Pentazocine } & haloperidol \\
Sigma-2 & {$\left[{ }^{3} \mathrm{H}\right] \mathrm{DTG}$} & haloperidol \\
5-HT2A & {$\left[{ }^{3} \mathrm{H}\right]$ Ketanserin } & chlorpromazine \\
5-HT2B & {$\left[{ }^{3} \mathrm{H}\right] \mathrm{LSD}$} & methysergide \\
5HT3 & {$\left[{ }^{3} \mathrm{H}\right]$ LY278584 } & LY278584 \\
Alpha2A & {$\left[{ }^{3} \mathrm{H}\right]$ Clonidine } & oxymetazoline \\
Alpha2C & {$\left[{ }^{3} \mathrm{H}\right]$ Clonidine } & prazosin \\
M4 & {$\left[{ }^{3} \mathrm{H}\right] \mathrm{QNB}$} & atropine \\
\hline
\end{tabular}

Detailed protocols (including cell handling, buffer composition, assay conditions, etc.) for all assays are available online (http://pdsp.med.unc.edu/ UNC-CH\%20Protocol\%20Book.pdf) 